\title{
Digenean trematodes of Seriolella porosa (Pisces, Centrolophidae) in San Matías Gulf, Argentina
}

\author{
Silvia E. Guagliardo', Carla B. Schwerdt', Sergio R. Martorelli², Noelia A. Galeano ${ }^{1}$ and Ruben D. Tanzola1* \\ ${ }^{1}$ Universidad Nacional del Sur, San Juan 670 (8000) Bahía Blanca; ${ }^{2}$ CEPAVE (CONICET-U.N.L.P) 2 N 584 (1900) La Plata; Argentina
}

\begin{abstract}
Seriolella porosa (Silver warehou) is an important fish resource in the Argentine Sea. No previous studies have been carried out to date on its parasite fauna. The present study aims to (i) identify the digenean trematodes that parasitize Silver warehou, (ii) estimate parasite frequency and abundance, and (iii) establish their relationship with fish size and sex. A total of 100 specimens of S. porosa from San Matías Gulf, Argentina were examined between September and October 2006. Host size and sex were determined. Parasites extracted from the stomach lumen were fixed, conserved in 5\% formalin, and stained with Langeron's hydrochloric carmine. The following parameters were also determined: dispersion coefficient, prevalence, intensity, and parasite abundance. Differences in parasitism were assessed using non-parametric tests. Four adult digenean species were found in the stomach, namely Lecithocladium cristatum, Aponurus laguncula, Elytrophalloides oatesi and Gonocerca cf. phycidis. L. cristatum was not only dominant but also the most prevalent and abundant species. None of the digeneans showed interspecific association with each other and therefore they might follow different patterns of colonization (i.e., different intermediate hosts, seasonal and/or spatial distribution of the infective stages). Significant differences were observed among the digeneans analyzed in respect to the sex of the host. Results from this study show that Silver warehou plays a key role as a final host of a significant number of digeneans in the ecosystem. This study is the first step in an attempt to further determine the larval stages in intermediate hosts in San Matías Gulf.
\end{abstract}

\section{Keywords}

Digenea, fish, Seriolella porosa, Argentina

\section{Introduction}

The Silver warehou, Seriolella porosa Guichenot, 1848 is a benthopelagic fish species that lives in the southwest Atlantic Ocean between parallels $35^{\circ}$ and $55^{\circ} \mathrm{S}$ (Garciarena and Perrotta 2002). It is seasonally present in San Matías Gulf, Argentina, the site of reproductive aggregation and spawning of this species (Forciniti and Pérez Macri 1992, Perier and Di Giácomo 2002). In the Argentine Sea, the highest landings are in Mar del Plata port (47\%), followed by San Antonio Oeste $(25 \%)$. Catches have shown an increasing trend since 1972 and have been exported as frozen fish and, to a lesser extent, sold as fresh fish in the local market (Cousseau and Perrotta 1998).

At present, there are no previous studies in Argentina on the systematics of helminth parasites of Silver warehou. Research on this host species contributes to knowledge about the sanitary state of Silver warehou as they have a relevant role in the transmission of infective stages, as well as interpreting the trophic and ecological relationships among the different components of the ecosystem.

In view of the above, the purpose of this study was to characterize the composition of digenean species hosted by $S$. porosa in San Matías Gulf and to evaluate some of the ecological implications for its parasite community.

\section{Materials and methods}

A total of 100 specimens of $S$. porosa ( 68 males and 32 females) were examined between September and October 2006. The area of capture was the northern sector of San Matías Gulf $\left(41^{\circ} 00^{\prime} \mathrm{S}, 64^{\circ} 00^{\prime} \mathrm{W}\right)$, Argentina. The fish were caught by the commercial fleet trawlers from San Antonio Oeste port. Host size and sex were determined. Parasites were extracted from the digestive lumen and were subsequently relaxed in hot saline solution. They were fixed, conserved in 5\% formalin and stored in 
$70 \%$ alcohol. Part of the helminth sample was stained with Langeron's hydrochloric carmine cleared in clove oil and mounted in Canada balsam. Diagrams were made at scale using a camera lucida. Measurements were all in micrometers $(\mu \mathrm{m})$. Average value and range were indicated in brackets. Sucker ratio was expressed as the ratio $=$ ventral sucker length + ventral sucker width/oral sucker length + oral sucker width.

Parasite prevalence, abundance and intensity of infection were calculated following Bush et al. (1997). Dispersion coefficient was calculated (DC: variance/media relationship according to Morales and Pino de Morales 1987). Male prevalence was compared to female prevalence by means of log-likelihood "G" test (Zar 1999). Also, the total number of parasites in males was compared to that in females via nonparametric Mann-Whitney U test (Siegel and Castellan 1995). The qualitative association between pairs of parasite species was estimated via the correlation $\Phi$ coefficient (Combes 1983). The relationship between parasite intensity and host size was estimated using Spearman's rank correlation coefficient (Siegel and Castellan 1995).

The material analyzed in the present study was deposited in the Collection of Invertebrates (Helminths) in the Museo de Ciencias Naturales in La Plata, Argentina.

\section{Results}

Family Hemiuridae Looss, 1899

Subfamily Elytrophallinae Skryabin et Gushanskaya, 1954

Lecithocladium cristatum (Rudolphi, 1819) Looss, 1907 (Fig. 1, Table I)

Site of infection: Stomach. Voucher specimens: MLP 5935.

Prevalence of infection: $80.19 \%$.

Mean intensity: 22.32.

Abundance: 17.90 .

Dominance: $78.30 \%$.

\section{Comments}

The specimens in the present study were found to belong to the Lecithocladium genus (Rudolphi, 1819) Looss, 1907 considering the following characteristics: body with strongly marked plications; oral infundibular sucker elongated pharynx; seminal vesicle with thick muscular wall located in the hindbody; narrow sinus-sac at the level of ventral sucker; not reaching the position of the seminal vesicle; absence of prostatic vesicle and tubular vitellarium composed of 7 elongated lobes.

In a study on hemiurids in fish from the North Atlantic Ocean, Gibson and Bray (1986) revised the species of Lecithocladium and divided them into seven groups according to body size, sucker ratio and egg length. Based on these parameters, the digenean species studied in our research could

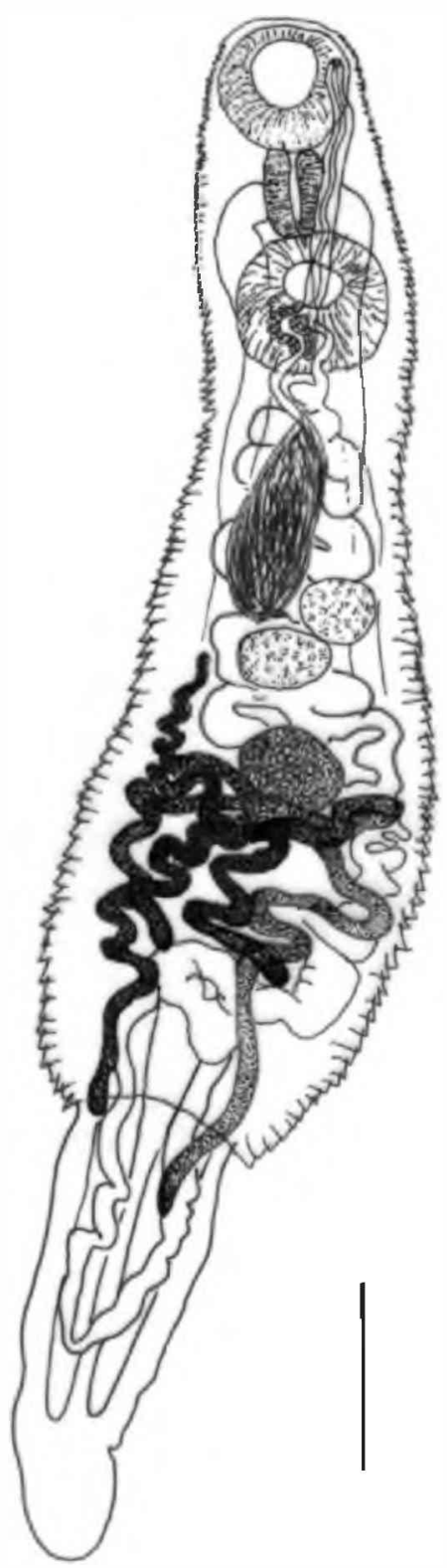

Fig. 1. Lecithocladium cristatum (schematic, in toto). Scale bar $=$ $0.5 \mathrm{~mm}$

have been included in the group that Gibson and Bray (1986) designated as group $\mathrm{F}$ to which $L$. harpodontis belongs, considering the total length of the body plus the ecsoma (both reaching a length of $6 \mathrm{~mm}$ ), the similarity in size between the oral sucker and the ventral sucker (which can, in fact, be slightly larger) and the length of eggs (from 12 to $20 \mu \mathrm{m}$ ). However, our species differs from $L$. harpodontis because in the latter the oral sucker was longer than the ventral one and sucker ratio is $1: 1$. In contrast, in our study the ventral sucker was slightly larger than the oral one and sucker ratio was 1:1.21. The Lecithocladium species from S. porosa also differs from $L$. harpodontis because its seminal vesicle was saccular, the pars prostatica straight (vs S-shaped pars prostatica) and the 
Table I. Comparative data on the morphometry of Lecithocladium cristatum (Rudolphi, 1819) Looss, 1907

\begin{tabular}{lccc}
\hline & Luque and Oliva (1993) & Zdzitowiecki (1997) & Present study (n= 15) \\
\hline Body length & $4640(1700-9400)$ & $1300-4600$ & $2608(2060-3570)$ \\
Body width & $900(400-1740)$ & $500-1150$ & $592.7(410-910)$ \\
Ecsoma length & $1820(130-4420)$ & $600-1800$ & $1503.57(1375-1790)$ \\
Pre-oral lobe & - & & $10-20$ \\
Oral sucker length & $200(160-230)$ & $226-320$ & $282.7(180-360)$ \\
Oral sucker width & $200(160-230)$ & $143-182$ & $212.7(140-370)$ \\
Ventral sucker length & $230(200-240)$ & $228-515$ & $301.3(210-430)$ \\
Ventral sucker width & $230(200-240)$ & $277-506$ & $256.7(160-410)$ \\
Sucker ratio VO/VV & $1: 1.15($ width ratio) & $1: 0.89-0.93(1$ ength ratio) & $1: 1.13(1: 0.9-1: 1.34)$ \\
Pharynx length & - & $167-330$ & $175.2(122.5-240)$ \\
Pharynx width & - & $87-209$ & $107.5(65-170)$ \\
Testicle length & $130(100-160)$ & & $156.2(110-210)$ \\
Testicle width & $130(100-160)$ & $300-420$ & $140.9(90-180)$ \\
Sinus sac length & - & $30-42$ & $400-450$ \\
Sinus sac width & - & & $38-40$ \\
Genital atrium length & & $210-495$ & $100-120$ \\
Seminal vesicle length & $150(130-170)$ & $130-330$ & $310(170-550)$ \\
Seminal vesicle width & 19 & - & $123(80-180)$ \\
Ovary length & 9 & $18-24$ & $132.86(70-190)$ \\
Ovary width & & $11-14$ & $122.86(60-150)$ \\
Egg length & & & $16.27(12.5-17.5)$ \\
Egg width & & & $10(7.5-12.5)$ \\
\hline
\end{tabular}

eggs were larger. The eggs were also larger than those of L. chaetodipteri and L. excisum (Fabio 1988) which have been reported to parasitize fish from the southwest Atlantic Ocean.

In addition, two species of Lecithocladium have been found in congeneric fish, one of which corresponds to $L$. seriolellae from New Zealand (Manter 1954) and the other was L. cristatum from Peru and Chile (Luque and Oliva 1993). The species found in our research differs from $L$. chaetodipteri due to the relation of the width of suckers, the length of the sinussac and the fact that the vitellarium does not penetrate into the ecsoma, and from $L$. excisum due to the size of the ventral sucker, which is, in fact, smaller than the oral sucker. Also, its sinus-sac was shorter and lies anteriorly to the ventral sucker. Our species was also different from $L$. seriolellae (Manter 1954) because the latter was smaller and also the sinus-sac begins anteriorly to the ventral sucker, whereas in our species the sinussac rised exactly at the level of the ventral sucker.

As for $L$. cristatum, the specimens studied in the present research show remarkable similarities mainly in their measurements (Table I), length of the vitellarium, length of the sinussac and sucker ratio, and in a tendency of the acetabulum to be slightly larger than the oral sucker. In view of all the above, it can be concluded that the species found in $S$. porosa coincides with $L$. cristatum.

It is also important to note that $L$. cristatum was previously cited in S. violacea in Peru and Chile and was also found in the South Atlantic where it had been cited as L. falklandicus by Gaevskaya and Kovaleva (1978) after which synonymy between the latter and L. cristatum was established by Luque and Oliva (1993).
Elytrophalloides oatesi (Leiper et Atkinson, 1914) Szidat et Graefe, 1967 (Fig. 2, Table II)

Site of infection: Stomach.

Voucher specimens: MLP 5936.

Prevalence of infection: $31.68 \%$.

Mean intensity: 14.37 .

Abundance: 4.55 .

Dominance: $19.92 \%$.

\section{Comments}

The following characteristics allowed us to include Elytrophalloides oatesi in the Elytrophalloides genus: presence of a long and thin sinus-sac, tegument with plications, long seminal vesicle with thick muscular walls and vitelline tear-shaped lobes.

Bray (1990) recognized only two valid species, namely E. oatesi Szidat et Graefe, 1967 and E. humerus Bray, 1990.

The measurements of the specimens in the present research coincide, in general, with the ranges of variability reported for $E$. oatesi, however, they are smaller than the specimens studied by Suriano and Sutton (1981). On the other hand, our specimens do not have the typical "shoulder-pads" that are present in other species of the genus.

Elytrophalloides oatesi has been cited in 52 fish species (Bray 1990) all over the world. According to Rodyuk and Jessen (1981) it is the most commonly recorded parasite in the Subantarctic area. In Argentina there are records in 12 fish species (Szidat and Graefe 1968; Suriano and Sutton 1981; Gaevskaya et al. 1990; Szidat 1950, 1955, 1961; MacKenzie and Longshaw 1995; Rodyuk 1995; Sardella and Timi 1996). 


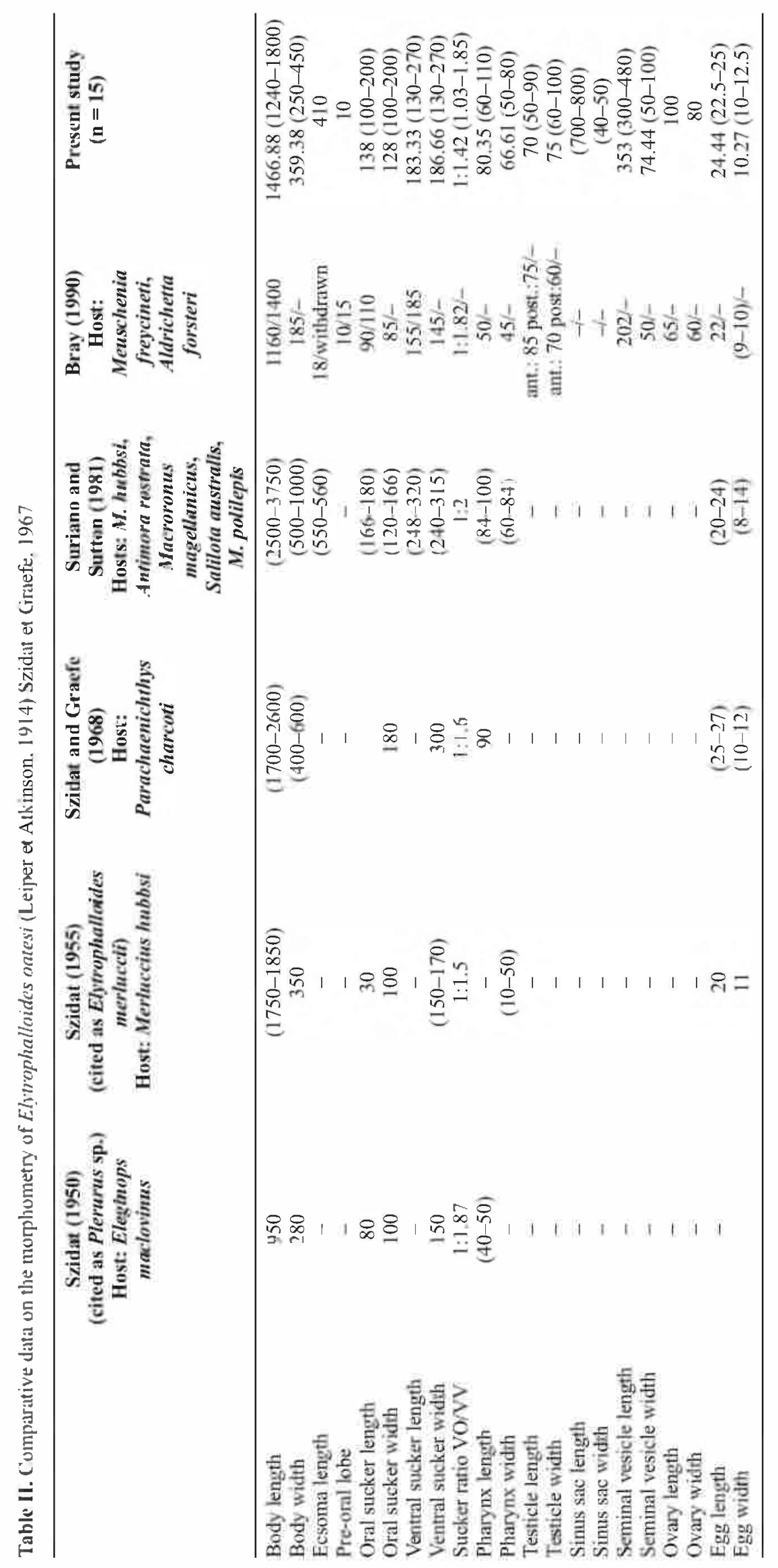




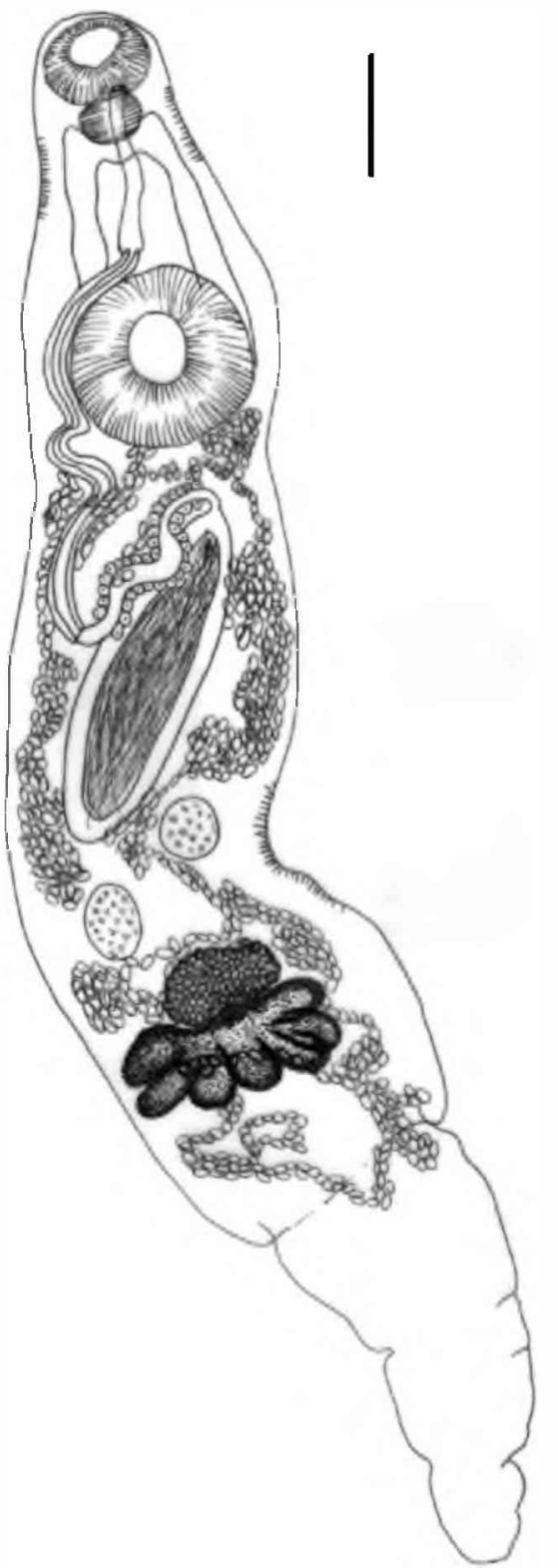

Fig. 2. Elytrophalloides oatesi (schematic, in toto). Scale bar $=0.2 \mathrm{~mm}$

$E$. oatesi has also been cited in approximately 11 fish species from waters adjacent to the Malvinas (= Falkland) Islands (Zdzitowiecki 1997, Kohn et al. 2007). Our research reports the first citation of $E$. oatesi in Silver warehou, S. porosa.

Family Lecithasteridae Odhner, 1905

Subfamily Lecithasterinae Odhner, 1905

Aponurus laguncula Looss, 1907 (Fig. 3, Table III)

Site of infection: Stomach.

Voucher specimens: MLP 5938.

Prevalence of infection: $19.80 \%$.

Mean intensity: 2.

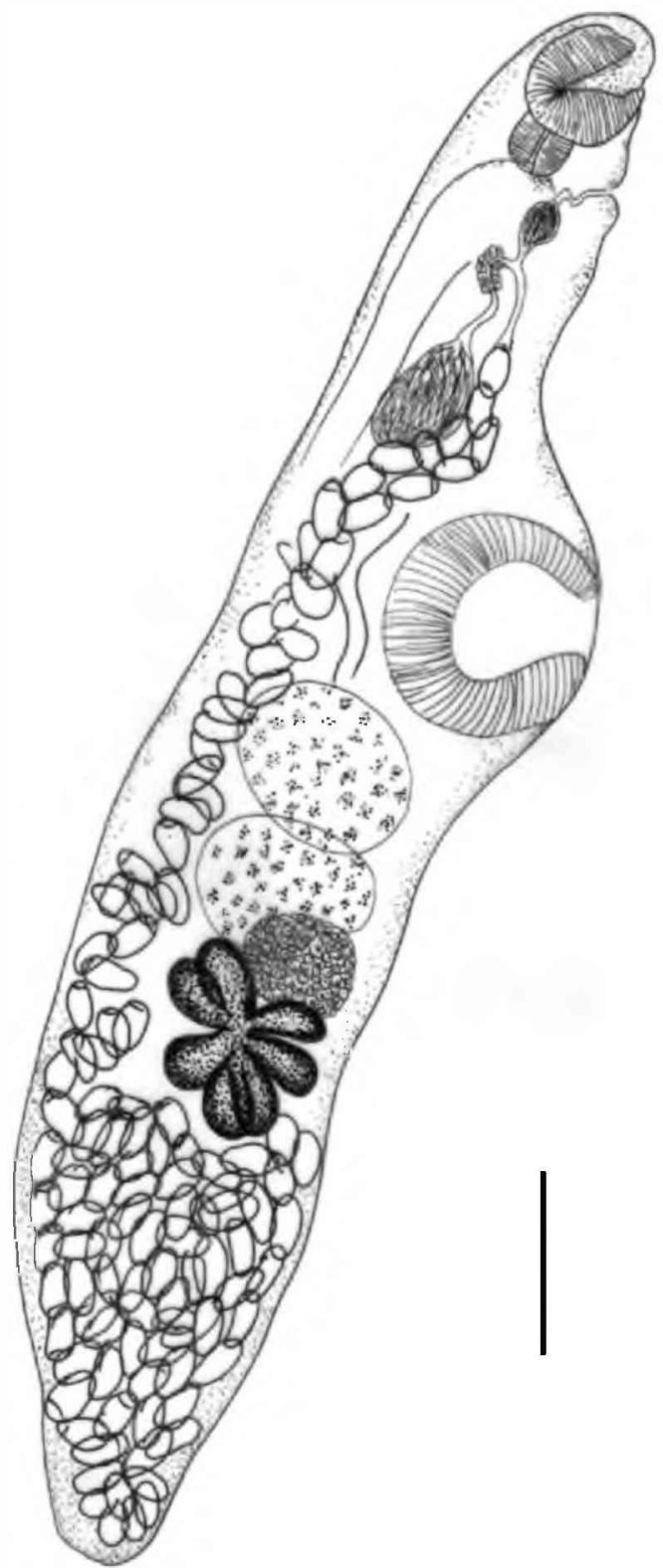

Fig. 3. Aponurus laguncula (schematic, in toto). Scale bar $=0.1 \mathrm{~mm}$

Abundance: 0.40 .

Dominance: $1.3 \%$.

\section{Comments}

These digeneans coincide in general with those in Aponurus Looss, 1907, whose type species is A. laguncula, due to the following characteristics: relatively small body, absence of spines and ecsoma, vitellarium of tear-shaped lobes and absence of genital atrium. This genus has been considered to be very close to the genera Lecithophyllum Odhner, 1905 and Brachadena Linton, 1910, however, some authors have reported differences between Brachadena and Lecithophyllum, e.g., the presence of a different genital atrium (Margolis 1958) and 
Table III. Comparative data on the morphometry of Aponurus laguncula Looss, 1907

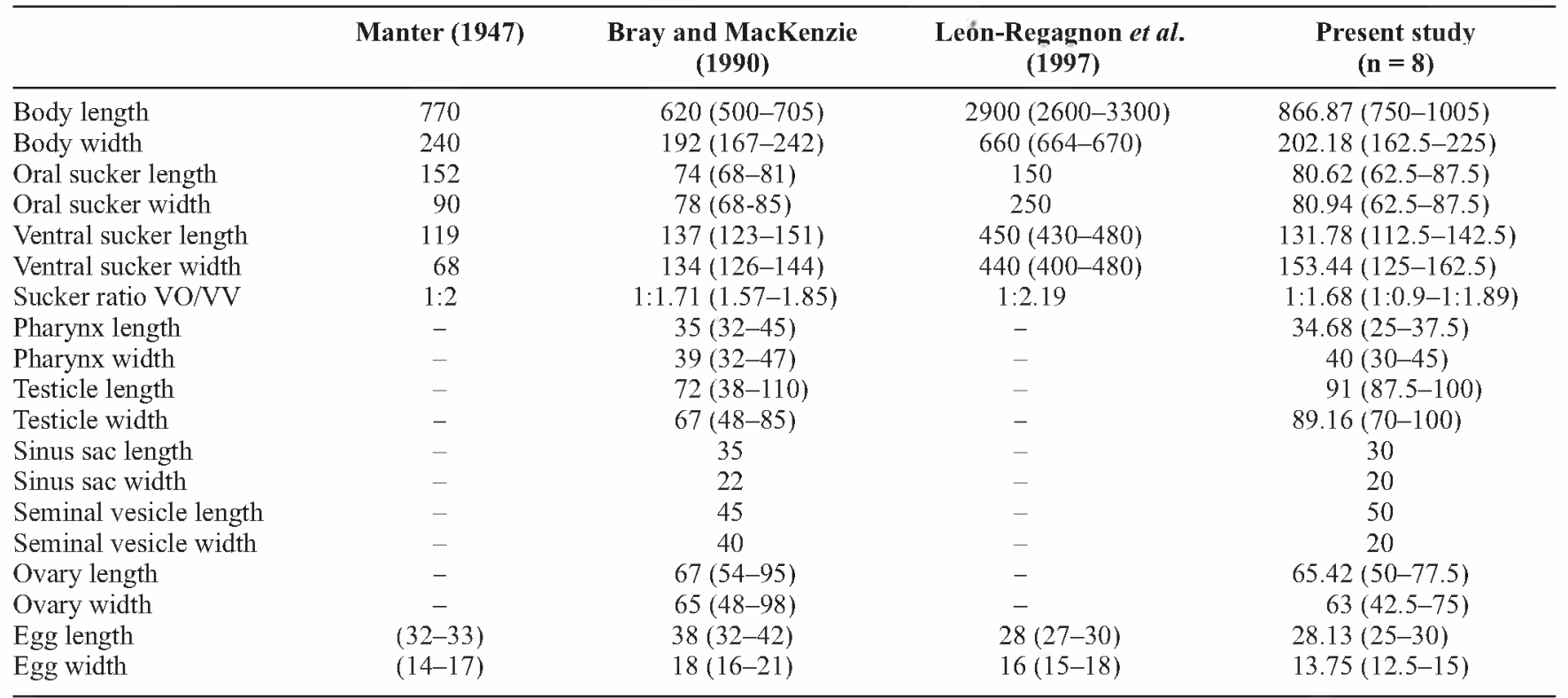

different egg size (Manter 1947). Later, Overstreet (1973) and Gibson and Bray (1979) considered the possibility of establishing synonymy between Lecithophyllum and Aponurus. Although Margolis (1958) differentiated Brachadena from Lecithophyllum and Aponurus, as its vitellarium consisted of seven ventrally bound lobes, Overstreet (1973) analyzed the type species and found that the lobes of the vitellarium were not ventrally bound and therefore included it in the Aponurus genus. However, according to Bray and Cribb (2000) further studies on the genital atrium and the vitelline lobes may revalidate the Brachadena genus.

Our specimens do not seem to have a well-defined genital atrium, which is why they cannot be included in the Lecithophyllum genus. However, the first section of the hermaphroditic duct shows a dilation which looks like the so-called hermaphroditic vesicle described by Yamaguti (1971) for this genus. The morphological characters of our specimens share major similarities with those reported by Bray and MacKenzie (1990) for Aponurus laguncula (Table III), showing, however, slight differences in the ranges of body and egg length recorded by these authors. Interestingly, Leon-Regagnon et al. (1997) have recorded very different measurements for A la guncula in comparison to those recorded by Bray and MacKenzie (1990), who considered it as a generalist due to its distribution. In fact, A. laguncula has been cited in 60 species of teleost fishes belonging to 27 families, displaying a high prevalence in clupeids (Mamaev 1970). The first citation of the genus in the South Atlantic belongs to Szidat (1950) who reported Aponurus sp. in Eleginops maclovinus. Later, in 1961, Szidat cited A. laguncula in Paralichthys patagonicus from waters of the Patagonian Shelf, which is the first record for $S e$ riolella porosa.
Family Derogenidae Nicoll, 1910

Subfamily Gonocercinae Skryabin et Gushanskaya, 1955

Gonocerca cf. phycidis (Fig. 4, Table IV)

Site of infection: Stomach.

Voucher specimens: MLP 5937.

Prevalence of infection: $0.99 \%$.

Mean intensity: 1.

Abundance: 0.01 .

Dominance: $0.04 \%$.

Table IV. Comparative data on the morphometry of Gonocerca ef. phycidis

\begin{tabular}{lcc}
\hline & $\begin{array}{c}\text { Suriano and Sutton } \\
(\mathbf{1 9 8 1 )}\end{array}$ & $\begin{array}{c}\text { Present study } \\
(\mathbf{n}=\mathbf{1})\end{array}$ \\
\hline Body length & $2600-4000$ & 1850 \\
Body width & $850-1100$ & 450 \\
Oral sucker length & $300-350$ & 200 \\
Oral sucker width & $550-600$ & 232.5 \\
Ventral sucker length & $700-750$ & 310 \\
Ventral sucker width & $900-950$ & 400 \\
Sucker ratio VO/VV & $1: 2-3$ & $1: 1.64$ \\
Pharynx length & $90-95$ & 90 \\
Pharynx width & $150-160$ & 80 \\
Testicle length & - & 150 \\
Testicle width & - & 150 \\
Ovary length & - & 100 \\
Ovary width & - & 95 \\
Egg length & 40 & 30 \\
Egg width & 20 & 16 \\
\hline & & Unauthenticated \\
& Download Date $\mid 8 / 26 / 19$ & $8: 03$ PM
\end{tabular}




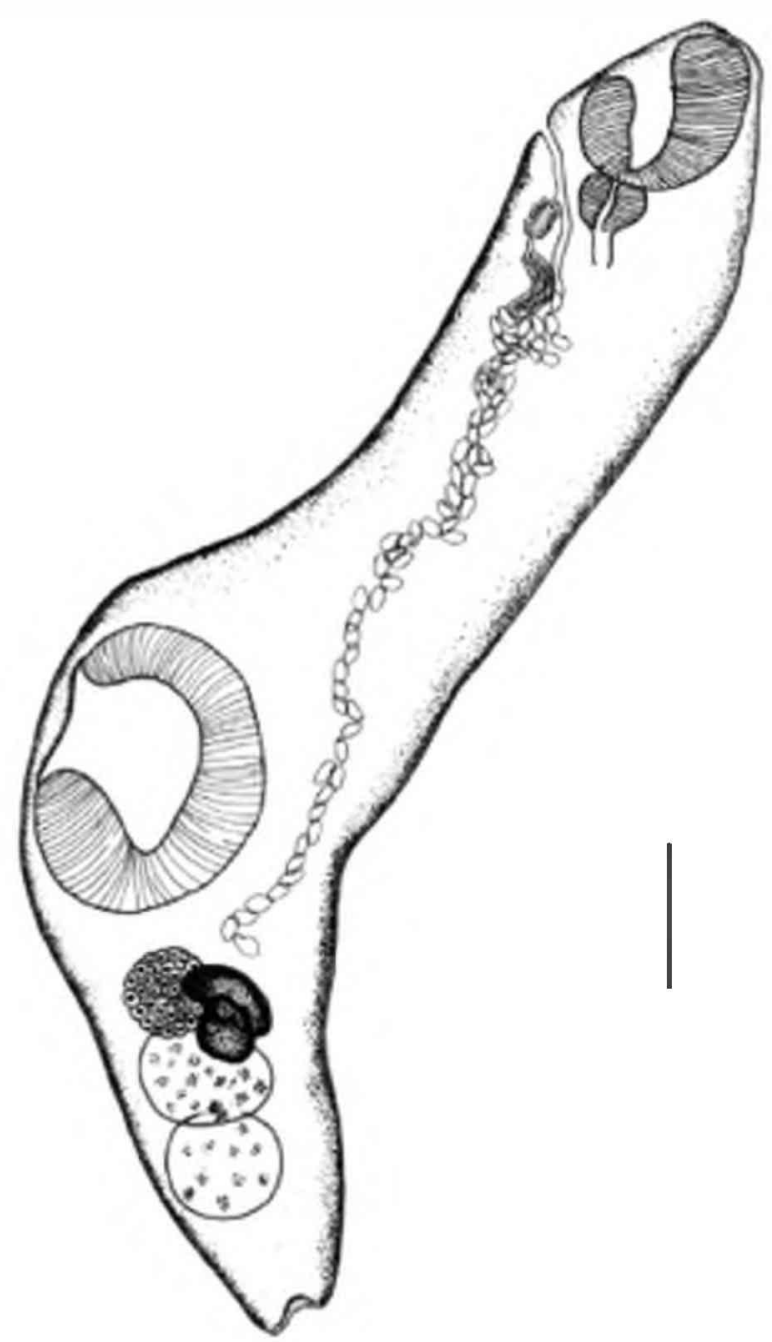

Fig. 4. Gonocerca cf. phycidis (schematic, in toto). Scale bar $=0.2 \mathrm{~mm}$

\section{Comments}

In the present study this species was recorded only once and only one specimen was found. This species was included in the genus Gonocerca Manter, 1925 in view of the following characteristics: presence of an elongated body without spines, testicles in tandem or symmetric, median genital pore located in the posterior margin of the oral sucker, hermaphroditic duct and absence of a sinus-sac, thin genital atrium, well-developed pars prostatica, free external club-shaped seminal vesicle and medium-sized pre-testicular ovary and vitellarium in the form of two pre-testicular masses lateral to the ovary and more or less lobulated. Zdzitowiecki (1997) recognized two species of Gonocerca in Antarctic and Subantarctic waters, namely $G$. lobata and $G$. phycidis, both showing differences in egg size. Based on this characteristic, the digenean species found in our study resembles $G$. phycidis. The latter has been cited in deep-water fish (Bray et al. 1999, Karlsbakk et al. 2002, Klimpel et al. 2001). It has been cited in 14 fish species from the Antaretic region and in 15 fish species from the Subantaretic region (Zdzitowiecki 1997) of the Atlantic Ocean. In Argentina it was cited by Szidat (1955), Gaevskaya and Kovaleva (1977), Suriano and Sutton (1981), Laskowski and Zdzitowiecki (2005). The measurements of the only specimen found in this study are included in Table IV. It is comparatively smaller than those studied by Suriano and Sutton (1981). Nonetheless, this difference could be attributed to intraspecific variations not included here in the absence of a range of measurements. Further studies on a larger number of specimens will therefore be necessary to confirm that this digenean specimen belongs to the species $G$. phycidis in which it is temporarily included.

\section{Quantitative aspects}

A total of 2,309 specimens of digeneans were recorded in the hosts examined in the present study, L. cristatum being the most dominant, prevalent and abundant.

All species were community components with prevalences higher than $10 \%$, with the exception of $G$. cf. phycidis in which only one individual was recorded, showing an overdispersed distribution.

The comparison of the prevalences between host sexes only revealed significant differences in A. laguncula in which males were found to be more parasitized. A similar pattern was observed when the total number of parasites in each sex were compared $(\mathrm{U}=825.50, \mathrm{p}=0.042)$. Nonetheless, these values may simply represent a sampling effect ( 65 males vs $32 \mathrm{fe}$ males) and may have no particular biological significance.

None of the species showed any interspecific association with each other (coefficient $\Phi: L$. cristatum-A. laguncula $=$ $0.082 ;$ L. cristatum-E. oatesi $=-0.0015 ;$ A. laguncula-E. oatesi $=-0.018$ and therefore they might follow different patterns of colonization (i.e., different intermediate hosts, and seasonal and/or spatial distribution of the infective stages). The three component species showed a significant correlation with host size although this correlation was only marginally positive for E. oatesi ( $L$. cristatum: $\mathrm{r}_{\mathrm{s}}=-0.23, \mathrm{p}=0.010 ;$ A. laguncula: $\mathrm{r}_{\mathrm{s}}=-0.021, \mathrm{p}=0.036 ;$ E. oatesi: $\left.\mathrm{r}_{\mathrm{s}}=0.23, \mathrm{p}=0.022\right)$.

\section{Discussion}

All parasite species analyzed showed a type of overdispersed distribution. The lack of statistical association between parasite species may suggest different pathways of parasitic colonization. This agrees with one of the most common parasite distribution patterns in parasite populations (Esch and Fernandez 1993). The host size and age are important variables in explaining the variability in parasitofauna and therefore infracommunity parameters, suggesting modifications in the ecological relationships throughout the ontogeny of the hosts (Riffo 1991). Also, the fact that intensity was positively correlated with host size in $E$. oatesi seems to indicate that this species is transmitted by some selectively incorporated trophic item with higher abundance in larger hosts. 
Aponurus laguncula was more prevalent in male hosts which harbour a higher parasite numbers than female hosts. In addition, Perrier and Di Giácomo (2002) confirmed that reproductive aggregations with a male-female ratio of $2: 1$ were present in the study area, although the sample of hosts was unbalanced. This agrees with the male-female ratio in the sample found in our study and it may be the reason for the higher parasitism record shown by males which, as they are more abundant in the ecosystem, seem to be more exposed to metacercariae-infected preys.

The different species of Lecithocladium in the Northern Atlantic are transmitted by Philine aperta, an opisthobranch gastropod, as first intermediate host (Køie 1991). Nonetheless, metacercariae do not show high specificity to their hosts. Køie (op. cit.) demonstrated experimentally that Lecithocladium uses copepods as secondary hosts, whereas a ctenophore species and a polychaete have been found infected in the wild and they therefore behave as disseminators of infective stages. On the northeast coast of Africa, Reimer et al._(1975) found metacercariae of the Lecithocladium genus in two types of medusae, in Pleurobrachia sp., in two calanoid copepods and in six species of the chaetognath Sagitta. This genus has been also recorded in Australia, the Indian Ocean and China, among other places (Korotaeva 1969, Gu and Shen 1978, Bray and Cribb 2004). This shows the large amplitude of susceptible intermediate hosts and therefore increases the spatial distribution pattern of species, thus justifying the high prevalence observed in the sample studied in the present research. A similar situation occurs with A. laguncula. Although nothing is known about its life cycle, adult samples have been recorded in definitive hosts not only in a diverse variety of definitive hosts, but also within a vast distributional range (Bray and MacKenzie 1990). In spite of the fact that $E$. oatesi has been recorded in several teleosts from different geographical areas, this species is not considered as a cosmopolitan (Rocka 2006).

The pronounced differences in abundance and dominance between $L$. cristatum and the other three species described here and the absence of any association between the species might be due to the fact that each digenean species chooses different intermediate host species or because each digenean species uses its host species in a different way.

Iannacone (2003) did not find any digenean species parasitizing Seriolella violacea from Callao, Peru. However, Tantalean and Huiza (1994) cited the Lecithocladium genus in Peruvian waters, although they did not give any details about the host species. Rohde et al. (1980) only cited one digenean species, Syncoelium filiferum, in Seriolella brama from New Zealand, and Bray and Cribb (2003) reported Cephalolepidapedon warehou in the gut of Seriolella punctata from Tasmania. All these differences might be attributed to the different trophic preferences of the Seriolella species in each of the study area, and therefore, to a strong ecological component in the structuring of community assemblages.
As stated above, $G$. phycidis has been reported from deepwater hosts (Bray et al. 1999, Klimpel et al. 2001, Karlsbakk et al. 2002). However, in our study area, Silver warehou has been described as a species of pelagic and gregarious habits in the neritic region (Forciniti and Pérez Macri 1992). As to the co-occurrence of $G$. cf. phycidis and $E$. oatesi, it is noteworthy that Oliva (2001) also recorded both species in Macruronus magellanicus in Chilean waters.

The presence of Silver warehou in the northern area of San Matías Gulf and the fact that this region is used as a spawning area by this fish species might be related to the availability of food (Ramirez 1996). It seems likely that carriers of larval digeneans form part of the group of euphausiids and hyperiidean amphipods, which are food items for Silver warehou (Forciniti and Pérez Macri 1992). Another group of potential larval digeneans might be that of jellyfishes and chaetognaths, all of which, in general, leave no tracks as trophic items except for the parasites they transport.

The results obtained from the present study contribute to knowledge about the biodiversity in San Matías Gulf, as well as identifying the role that the Silver warehou plays as a definitive host to at least three digenean species in the ecosystem. This group of helminths in San Matías Gulf might establish the boundaries of different metapopulations, since no available parasite records for Seriolella species have shown as much species diversity as in the present study.

Acknowledgements. The authors are grateful to Mrs. Rosemary Scoffield for her assistance with the English language, and to Dr. Raúl González and Mr. Paul Osovnikar from the Instituto de Biología Marina y Pesquera Ate. Storni, province of Río Negro, Argentina, for their collaboration in obtaining the samples of Seriollela porosa.

\section{References}

Amato J.F.R. 1983. Digenetic trematodes of percoid fishes of Florianópolis, Southern Brasil-Pleorchiidae, Didymozoidae, and Hemiuridae, with the description of three new species. Revista Brasileira de Biología, 1, 99-124.

Bray R.A. 1990. Hemiuridae (Digenea) from marine fishes of the southern Indian Ocean: Dinurinae, Elytrophallinae, Glomericirrinae and Plerurinae. Systematic Parasitology, 17, 183 217. DOI: $10.1007 / \mathrm{BF} 00009553$

Bray R.A., Cribb T.H. 2000. A new species of Apomurus Looss, 1907 (Digenea: Lecithasteridae) in butterflyfishes (Perciformes: Chaetodontidae) from New Caledonia. Systematic Parasitol$o g y, 46,181-189$. DOI: 10.1023/A:1006346221319.

Bray R.A., Cribb T.H. 2003. New species of Opechona Looss, 1907 and Cephalolepidapedon Yamaguti, 1970 (Digenea: Lepocreadiidae) from fishes off northern Tasmania. Papers and Proceedings of the Royal Society of Tasmania, 137, 1-5.

Bray R.A., Cribb T.H. 2004. Species of Lecithocladium Lühe, 1901 (Digenea, Hemiuridae) from Australian marine fishes, with a description of a new species from various hosts off eastern Australia. Acta Parasitologica, 49, 3-11.

Bray R.A., Littlewood J.D.T., Hernion E.A., Williams B., Henderson R.E. 1999. Digenean parasites of deep sea teleosts: a re-

Unauthenticated

Download Date | 8/26/19 8:03 PM 
view and case studies intrageneric phylogenies. Parasitology, 119, 125-144.

Bray R.A., MacKenzie K. 1990. Aponurus laguncula Looss, 1907 (Digenea: Lecithasteridae): a report from herring, Clupea harengus L., in the eastern English Channel and a review of its biology. Systematic Parasitology, 17, 115-124. DOI: 10 1007/BF00009799.

Bush A.O., Lafferty K.D., Lotz J.M., Shostak A.W. 1997. Parasitology meets ecology on its own terms: Margolis et al. revisited Journal of Parasitology, 83, 575-583. DOI: $10.2307 / 3284227$.

Combes C. 1983. Aplication à l'écology parasitaire des indices d'association fondés sur le caractère présence-abscence. Vie et $\mathrm{Mi}$ lieu, 33, 203-212.

Cousseau M.B., Perrotta R.G. 1998. Peces marinos de Argentina Biología, distribución, pesca. Publicaciones Especiales INIDEP, Mar del Plata, Argentina, 163 pp.

Esch G.W., Fernández J.C. 1993. A functional biology of parasitism Chapman \& Hall, London, 337 pp.

Fabio S.P. 1988. Sobre tres Hemiuridae parasitos de peixes do litoral do Estado do Rio de Janeiro (Trematoda, Digenea). $A r$ quivos da Universidade Federal Rural do Rio de Janeiro, 11 , 45-49.

Forciniti L., Pérez Macri G.P. 1992. Contribución al aconocimiento del sistema digestivo y la alimentación del savorín (Seriolella porosa). Frente Maritimo, 12, 129-137.

Gaevskaya A.V., Kovaleva A.A. 1977. New species of trematodes from fishes of the Falkland Patagonian region (South Western Atlantic). Parazitologiya, 11, 417-423 (In Russian).

Gaevskaya A.V., Kovaleva A.A. 1978. Materials on fish trematodes in the southeastern Atlantic. Vestnik Zoologii, 3, 60-66 (In Russian)

Gaevskaya A.V., Rodyuk G.N., Parukhin A.M. 1990. Peculiarities and formation of parasitofauna of the Patagonian toothfish Dissostichus eleginoides. Biologiya Morya, 4, 23-28 (In Russian).

Garciarena A.D., Perrotta R.G. 2002. Características biológicas y de la pesca del savorín Seriolella porosa (Pisces: Centrolophidae) del Mar Argentino. INIDEP Informe Técnico, 49, 1-19.

Gibson D.I., Bray R.A. 1979. The Hemiuroidea: terminology, systematics and evolution. Bulletin of the British Museum (Natural History) (Zoology Series), 36, 35-146.

Gibson D.I., Bray R.A. 1986. The Hemiuridae (Digenea) of fishes from the northeast Atlantic. Bulletin of British Museum (Natural History) (Zoology Series), 51, 1-125.

Gu C., Shen J. 1978. Some dinurid trematodes (subfamily Dinurinae Looss, 1907) from marine fishes of economic importance of China. Acta Zoologica Sinica, 24, 377-387 (In Chinese).

Iannacone J. 2003. Tres metazoos parásitos de la cojinoba Seriolella violacea Gulchenot (Pisces, Centrolophidae) Callao, Perú. Revista Brasileira de Zoologia, 20, 257-260.

Karlsbakk E., Asphol P.E., Berg V., Hareide N.R., Berland B. 2002. Some parasites of the small-eyed rabbitfish, Hydrolagus affinis (Capello, 1867) (Holocephali), caught in deep waters off SW Greenland Sarcia. North Atlantic Marine Science, 87. 179-184. DOI: 10.1080/003648202320205256.

Klimpel S., Seehagen H., Palm H., Rosenthal H. 2001. Deep-water metazoan fish parasites of the world. Logos Verlag, Berlin, $315 \mathrm{pp}$

Kohn A., Fernandes B.M.M., Cohen S.C. (Eds.). 2007. South American Trematode Parasites of Fishes. Imprinta Express Ltda, Brazil, Rio de Janeiro, 318 pp.

Køie M. 1991. Aspects of the morphology and life cycle of Lecithocladium excisum (Digenea, Hemiuridae), a parasite of Scomber spp. Intenational Journal for Parasitology, 21, 597602. DOI: $10.1016 / 0020-7519(91) 90065-F$
Korotaeva V.D. 1969. Helminths of some food-fishes of the order Clupeiformes in the sea near Australia and New Zealand. Problemy Parasitologii, Trudy Nauchnoy Konferentsii Parasitologov, USSR, 6, 237-238 (In Russian).

Laskowski Z., Zdzitowiecki K. 2005. The helminth fauna of some notothenioid fishes collected from the shelf of Argentine Islands, West Antarctica. Polish Polar Research, 26, 315-324.

León-Règagnon V., Ponce de León G.P., Argumedo R.L. 1997. Hemiuriformes de peces marinos de la Bahía de Chamela, México, con la descripción de una nueva especie del género Hysterolecitha (Digenea: Hemiuridae: Lecithasterinae). Anales del lnstituto de Biologia, Universidad Nacional Autónoma de México, Serie Zoología, 68, 1-34.

Luque J., Oliva M. 1993. Trematodes of marine fishes from the Peruvian faunistic province (Perú and Chile) with a description of Lecithochirium callaoensis $\mathrm{n}$. $\mathrm{sp}$. and new records. Revista de Biologia Marina, Valparaiso, 28, 271-286.

MacKenzie K., Longshaw M. 1995. Parasites of the hakes Merluccius australis and $M$. hubbsi in the waters around the Falkland Islands, southern Chile, and Argentina, with an assessment of their potential value as biological tags. Canadian Journal of Fisheries and Aquatic Sciences, 52, 213-224.

Mamaev Y.L. 1970. Helminths of fishes of Gulf of Tong King In: (Eds. P.G. Oshmarin, Y.L. Mamaev and B.I. Lebedev) Helminths of animals of south-eastern Asia. Izd. Nauka. Moscow, 127-190 (In Russian).

Manter H.W. 1947. Digenetic trematodes of marine fishes of Tortugas, Florida. American Midland Naturalist, 38, 257-416. DOI: $10.2307 / 2421571$.

Manter H.W. 1954. Some digenetic trematodes from fishes of New Zealand. Transactions of the Royal Society of New Zealand. $82,475-568$

Margolis L. 1958. A new species of Lecithophyllum from north $\mathrm{Pa}$ cific fishes with a consideration of the taxonomy of the genera Lecithophyllum, Aponurus and Brachadena (Trematoda: Hermiuridae). Canadian Journal of Zoology, 36, 893-904. DOI: $10.1139 / \mathrm{z} 58-077$.

Morales G., Pino de Morales L.A. 1987. Parasitología Cuantitativa. Fundación Fondo Editorial Acta Científica Venezolana, Caracas, Venezuela, $132 \mathrm{pp}$.

Oliva M. 2001. Metazoan parasites of Macruronus magellanicus from southern Chile as biological tags. Journal of Fish Biology, 58, 1617-1622. DOI: 10.1006/jfbi.2001.1569.

Overstreet R.M. 1973. Some species of Lecithaster Lühe, 1901 (Digenea: Hemiuridae) and related genera from fishes in the northern Gulf of Mexico. Transactions of the American Microscopical Society, 92, 231-240. DOI: 10.2307/3224920.

Perier M., Di Giácomo E. 2002. El savorín Seriolella porosa como un recurso estacional en el Golfo San Matías, República Argentina. Revista Investigación de Desarrollo Pesquero, 15. $15-26$.

Ramírez F.C. 1996. Composición, abundancia y variación estacional del zooplancton de red del Golfo San Matías. Frente Maritimo, 16, 156-167.

Reimer L.W., Hnatiuk S., Rochner J. 1975. Metacercarien in Planktotieren des mittleren Atlantik. Wissenschaftliche Zeitschrift der Pädagogischen Hochschule 'Liselotte Herrmann' Güstrow, 2, 239-258.

Riffo L. 1991. La fauna de parásitos metazoos del lenguado de ojo grande Hippoglossina macrops Steindachner, 1876 (Pisces: Bothidae): una aproximación ecológica. Medio Ambiente, 11. $54-60$.

Rocka A. 2006. Helminths of Antarctic fishes: life cycle biology, specificity and geographical distribution. Acta Parasitologica, 51, 26-35. DOI: $10.2478 / \mathrm{s} 11686-006-0003-\mathrm{y}$.

Download Date | 8/26/19 8:03 PM 
Rodyuk G.N. 1995. Myctophidae. Parasitofauna of the world ocean Biology and dynamics of fishes and invertebrates abundance in the Atlantic Ocean. Trudy Atlant NIRO, 100-117 (In Russian).

Rodyuk G.N. Jessen O. 1981. Parasitic fauna of the fishes of the Atlantic part of the Antarctic (South Georgia Island and South Shetland Isles). In: (Eds. O.N. Bauer, P.I. Gerasev, A.V. Gussev, E.V. Zhukov, V.G. Kulachkova, Yu.I. Polyanskiy and T.A. Timofeeva) Abstracts of Communications. Symposium on Parasitology and Pathology of Marine Organisms. Izd. Nauka, Leningrad, 102-104 (In Russian).

Rohde K., Roubal F., Hewitt G.C. 1980. Ectoparasitic Monogenea, Digenea, and Copepoda from the gills of some marine fishes of New Caledonia and New Zealand. New Zealand Journal of Marine \& Freshwater Research, 14, 1-13.

Sardella N., Timi J. 1996. Parasite communities of Merluccius hubbsi from Argentinean-Uruguayan common fishing zone. Fisheries Research, 27, 81-88. DOI: 10.1016/0165-7836(95) 00460-2.

Siegel S., Castellan N.J. 1995. Estadística no Paramétrica aplicada a las ciencias de la conducta. Editorial Trillas, México, $437 \mathrm{pp}$.

Suriano D.M., Sutton C.A. 1981. Contribución al conocimiento de la fauna parasitológica Argentina. VII. Digeneos de peces de la plataforma del mar Argentino. Revista del Museo de la Plata (Nueva Serie, Sección Zoológica). 12, 261-271.

(Accepted November 3, 2009)
Szidat L. 1950. Los parásitos del róbalo (Eleginops maclovinus Cuv. \& Val). Primer Congreso Nacional de Pesquerías Marítimas e Industriales. Mar del Plata, Argentina (1949), 2, 235-270.

Szidat L. 1955. La fauna de parásitos de Merluccius hubbsi como carácter auxiliar para la solución de problemas sistemáticos y zoogeográficos del género Merluccius L. Comunicaciones Instituto Nacional de Ciencias Naturales, Museo Argentino de Ciencias Naturales Bernardino Rivadavia Ciencias Zoológicas, 4, 1-54.

Szidat L. 1961. Versuch einer Zoogeographie des Sud-Atlantik mit Hilfe von Leitparasiten der Meeresfische. Parasitologische Schriftenreihe, 13, 1-98.

Szidat L., Graefe G. 1968. The parasites of Parachaenichthys charcoti an Antarctic fish, in relation to problems of zoogeography. Symposium on Antarctic Oceanography (Santiago); International Council of Science Unions, Special Committee in Antarctic Research, 169-170.

Tantalean M., Huiza A. 1994. Sinopsis de los parásitos de peces marinos de la costa peruana. Biotempo, 1, 53-101.

Yamaguti S. 1971. Synopsis of digenetic trematodes of vertebrates. Vols 1 and 2. Keigaku, Tokyo, 1074 pp.

Zar J.H. 1999. Biostatistical analysis. 4 Ed. Prentice Hall, New Jersey, $663 \mathrm{pp}$.

Zdzitowiecki K. 1997. Antarctic Digenea, parasites of fishes. In: (Eds. J.W. Wägele and J. Sieg) Synopses of the Antarctic Benthos. 8. Koenigstein, Koeltz Scientific Books, 156 pp 